\title{
The Manufacturing Sector of Greece Before and During the Financial Crisis
}

\author{
John Chalikias ${ }^{1}$
}

\begin{abstract}
:
The Greek industry achieved its best performance in the 1970s when it participated in GDP with approximately $20 \%$ and around 400,000 employees or $12 \%$ of all employees. Today, the participation percentage of manufacturing in GDP has been reduced to $5.4 \%$ with 168,000 jobs or $4.5 \%$ of total employment.
\end{abstract}

The aim of this paper is to monitor through appropriate indicators the evolution of performance and competitiveness of Greek industry during the last twenty years to investigate the causes of the manufacturing industry decline.

More specifically, based on the updated data of the Hellenic Statistical Authority (ELSTAT) covering the period 1995 - 2013, the evolution of manufacturing economic fundamentals (investments, value added, employment, etc.), the export performance and evolution of competitiveness are analyzed.

By competitiveness we mean measurable factors, i.e. labor costs per unit of product and labor productivity in manufacturing.

Keywords: Manufacturing, investments, exports, competitiveness.

\footnotetext{
${ }^{1}$ An earlier version of this paper appeared in Greek Economic Outlook, Centre of Planning and Economic Research, Issue 32, February 2017, Athens University of Economics and Business \& Exports Research Centre of the Pan-Hellenic Exporters Association, e-mail: jh@aueb.gr
} 


\section{Introduction}

The sectoral analysis of the Greek economy both at static (input - output tables) and dynamic level (estimating macroeconomic models) is one of the main concerns of economists. Thus, many sectoral studies have been attempted in the past concerning the analysis of economic fundamentals such as consumption, investments, employment, etc., (Liapis et al., 2013; Thalassinos and Stamatopoulos, 2015).

This study seeks to fill a gap present in literature in examining the performance of Greek manufacturing in conjunction with the main determining factors thereof, such as competitiveness, investments and labor productivity. The Greek industry achieved its best performance in the 1970s when it participated in GDP with approximately $20 \%$ and around 400,000 employees or $12 \%$ of all employees. Today, the participation percentage of manufacturing in GDP has been reduced to 5.4\% with 168,000 jobs or $4.5 \%$ of total employment (Keisidou et al., 2013).

The aim of this paper is not the estimation of dynamic models but monitoring through appropriate indicators the evolution of performance and competitiveness of Greek industry during the last twenty years to investigate the causes of the manufacturing industry decline. Besides, the estimation of such econometric relationships between different variables is now of secondary importance, since the first step is the construction of single sets, which is the subject matter of the study.

More specifically, based on the updated data of the Hellenic Statistical Authority (ELSTAT) covering the period 1995-2013, the evolution of manufacturing economic fundamentals (investments, value added, employment, etc.), the export performance and evolution of competitiveness are analyzed. By competitiveness we mean measurable factors, i.e. labor costs per unit of product and labor productivity in manufacturing.

The Export Research Centre (KEEM) has published in the past similar studies on measuring the competitiveness of Greek manufacturing products, first for the entire industry and later for individual sectors (Export Research Center, 1985; 1987). The main cause for the delay of the analysis at sectoral level was the lack of sectoral data regarding employment, wages, etc. These data, although collected by the then National Statistical Service of Greece (ESYE), showed a lag in the time of their publication. However, thanks to the concerted efforts of ESYE and the Foundation for Economic and Industrial Research (IOBE), these data, after digitization and proper processing, were formed in complete single sets covering the period 19611992 with all fundamentals both for the entire industry and the basic, at two-digit level, industrial sectors, thus enabling a first sectoral approach (Export Research Center, 1995; Thalassinos and Dafnos, 2015; Thalassinos et al., 2015).

This study refers only to the large industry enterprises (average annual employment over 10 people) and is based on the revised data of the Hellenic Statistical Authority (ELSTAT). During the period 1995-2007, the manufacturing activity is broken down 
into 23 sectors according to the European System of National Accounts (NACE Revision 1.1), and for the period 2008-2013 into 24 sectors according to the newest Community Classification, (NACE Revision 2).

The lack of sectoral studies on the export performance of the Greek industry is also due to another important reason. The lack of matching between the classification systems of foreign trade and industrial activity. More specifically, in foreign trade the products are classified by either their use (food, raw materials, etc.) or the raw material they are made of (chemical products, manufactured goods classified mainly by raw material, etc.). Thus, the products are recorded based on the Standard International Trade Classification (SITC, Version 4.0). In contrast, in industry the products are classified based on the industrial sector producing them (outputs). It is therefore immediately understood how difficult it is to match the five-digit codes of the Standard International Trade Classification (SITC) system and the three-digit codes of the classification system of industrial sectors (NACE), which is partly covered by the Eurostat publications.

\section{Fundamentals of Manufacturing}

Investments made by industrial enterprises are a basic prerequisite for creating the industrial base of a country and expanding it through the establishment of large production units. Figure 1 shows total gross investments made by the large industry enterprises (average annual employment 10 people or more) in the period 19952013. The period 1995-2000 is characterized by high growth rates of investment in almost all industrial sectors, followed by a down trend in the next five years up to 2005 and a small recovery in 2006 and 2007. The spectacular increase in investments in 2008 is due to investments in the sectors of Oil and Coal and Chemical and Pharmaceutical Products. The investments of both these sectors almost increased fivefold in 2008 and represent $41.5 \%$ of total investments. The consecutive decline in manufacturing investments begins as from 2008 because of the country's economic crisis. Based on the currently available data, from 2008 up to 2013 investments decreased by $-60 \%$.

Investments come mainly from large industrial enterprises and pertain to new technologies and automatisms, so they do not necessarily mean establishing new enterprises or new jobs. Figure 2 is revealing about the evolution of the number of manufacturing enterprises in the period 1995-2013. Since the mid-90s, a consecutive decrease in the number of industrial enterprises is noted and continues until 2005 with a loss of 2,438 manufacturing units. A four-year period, 2005 - 2009, follows with an upward trend in the establishment of new enterprises because of the incentives established at that time for companies (reduction of corporate taxes, creating tax-free reserves, etc.). The favorable climate led to the establishment of new manufacturing units and from 3,376 in 2005 they rose to 4,098 in 2009. The economic crisis that followed in conjunction with the political uncertainty and tax increases led to the cessation of operations for a significant number of enterprises, which fell to 2,845 in 2013 . 
Figure 1: Total Investments in Manufacturing (€ million).

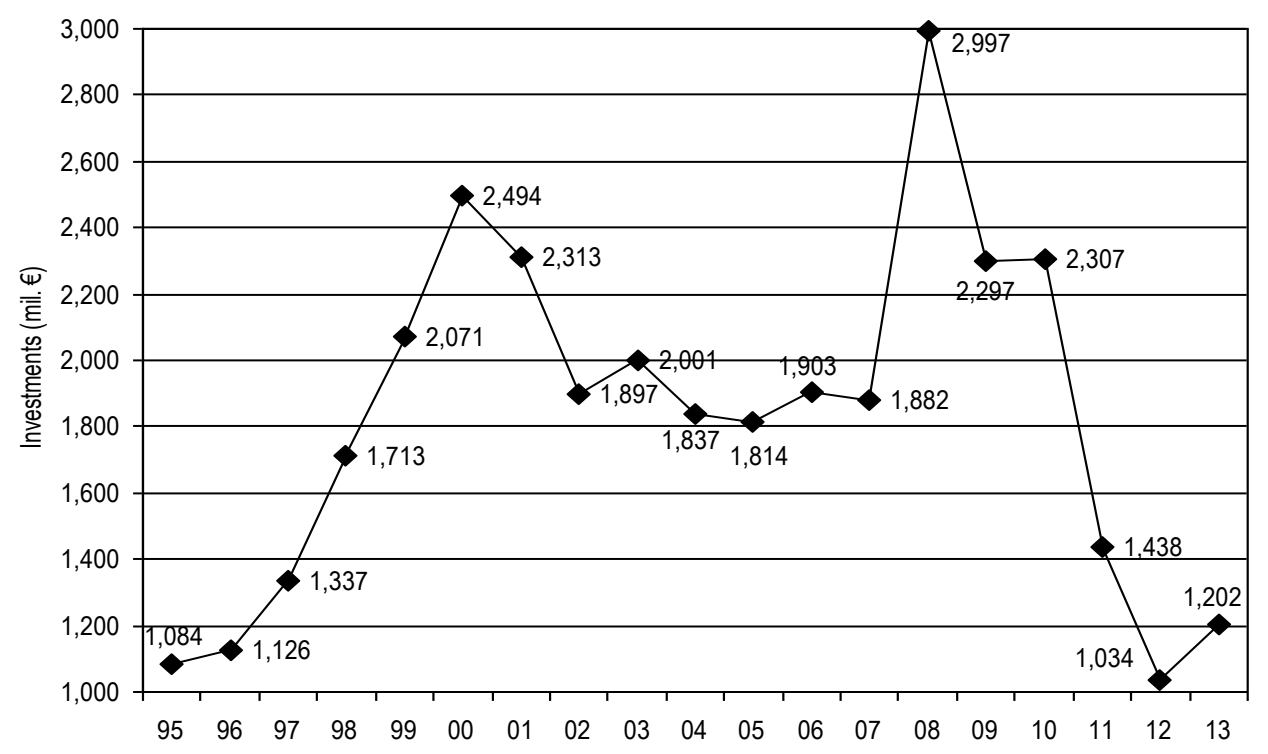

Figure 2: Number of Enterprises (over 10 people) and Number of Employees in Manufacturing.

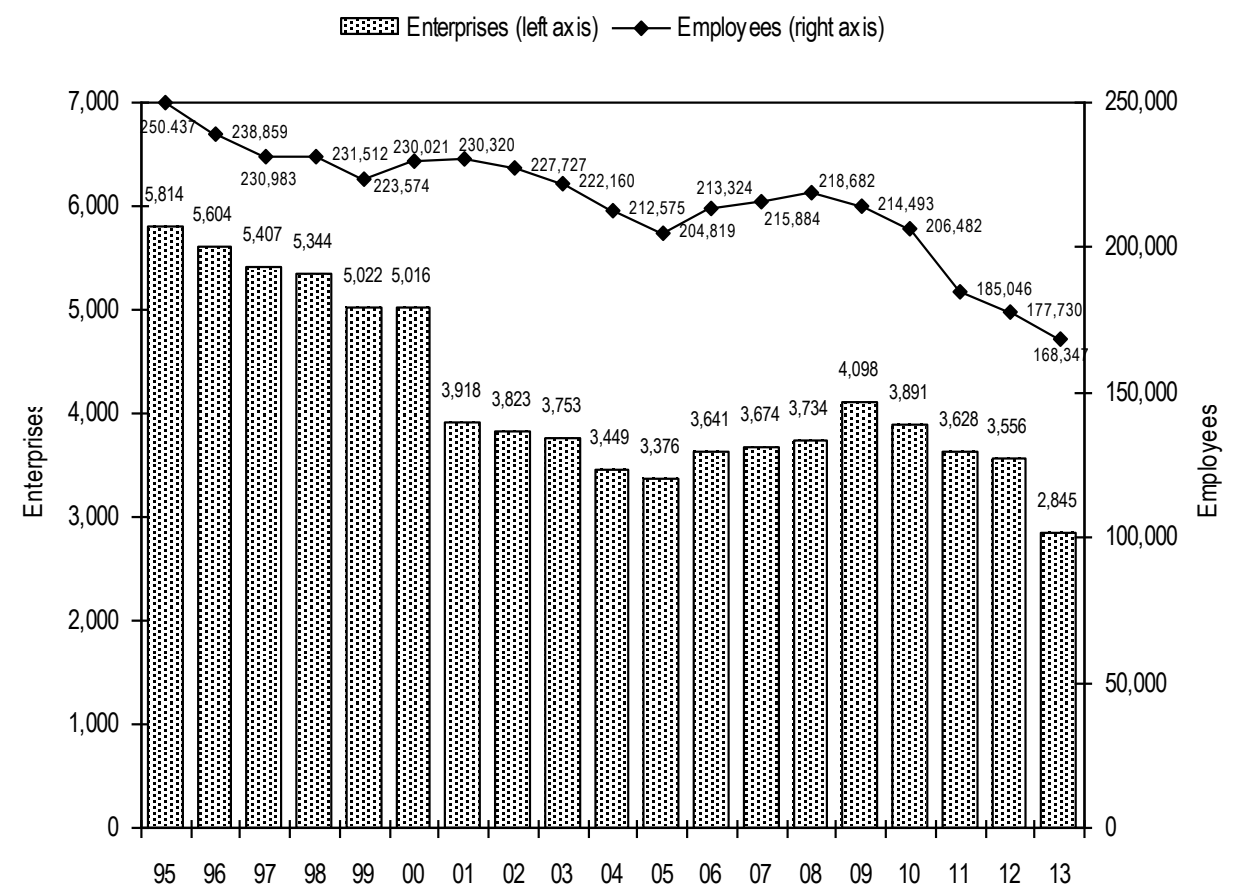


The evolution of the number of employees in manufacturing presents a similar picture. Cumulatively over the period 1995-2013 the jobs in manufacturing decreased by 81,653 people or by $-32.7 \%$. The only period when a slight increase in the number of employees is noted is the period 2005-2009 during which the number of new enterprises also increases.

Finally, regarding the gross manufacturing output, there is a high growth rate in the period 1995-2008 (Figure 3). Specifically, the gross output increased in total by $146.3 \%$ with an average annual growth rate of $+6,9 \%$. The picture is similar for the evolution of the value added of manufacturing with a cumulative increase of $98.5 \%$ and an average annual growth rate of $+5.4 \%$. After 2009 the picture changes. The gross output in 2009 decreases significantly by $-18.4 \%$ and then changes in a positive but low growth rate $(+1.6 \%)$. In contrast, the value added of manufacturing shrinks drastically with a cumulative decrease of $-28.4 \%$ in the period $2008-2013$, i.e. an average growth rate of $-7.7 \%$. The main reason for the decrease of value added in the period 2008 - 2013 is the collapse of investments mentioned above, resulting in the replacement of inputs (intermediate consumption) by domestic sources with inputs from abroad.

The result of these developments is the decrease in recent years of both the gross output consisted by the value added and the contribution of the manufacturing sector in the Gross Domestic Product (GDP). Figure 4 is revealing about the evolution of these two indices.

Figure 3: Gross Manufacturing Output ( $€$ million)

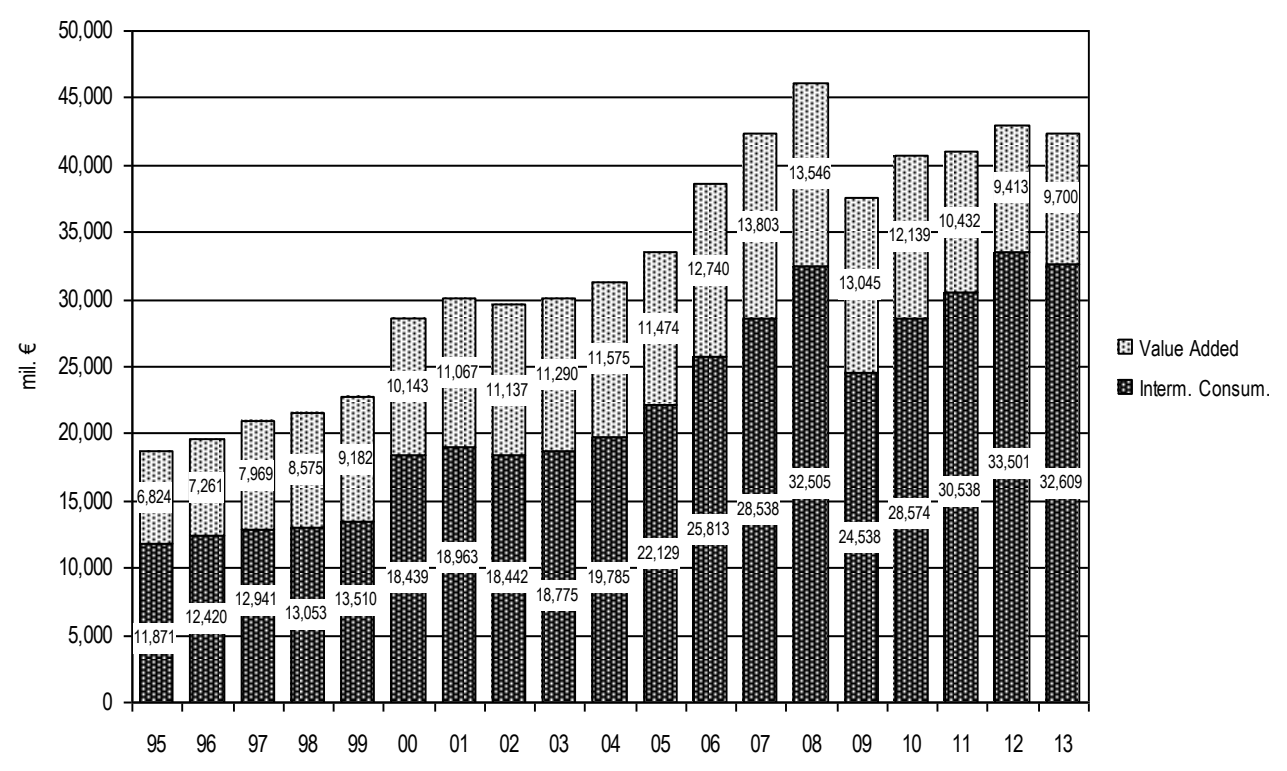


In the period 1995-2004 the value added was approximately $36 \%-40 \%$ of the gross manufacturing output. Since 2005, this percentage constantly decreases and fell to $22 \%$ and $23 \%$ in 2012 2013, respectively. The evolution of manufacturing participation in the GDP presents a similar picture. Over the period 1995-2001, the percentage of GDP coming from the manufacturing sector was about $7 \%$. Since 2002, the participation percentage constantly decreases and fell to $4.9 \%$ and $5.4 \%$ in 2012 and 2013, respectively.

Figure 4: Participation of Manufacturing Output Value Added (\%),

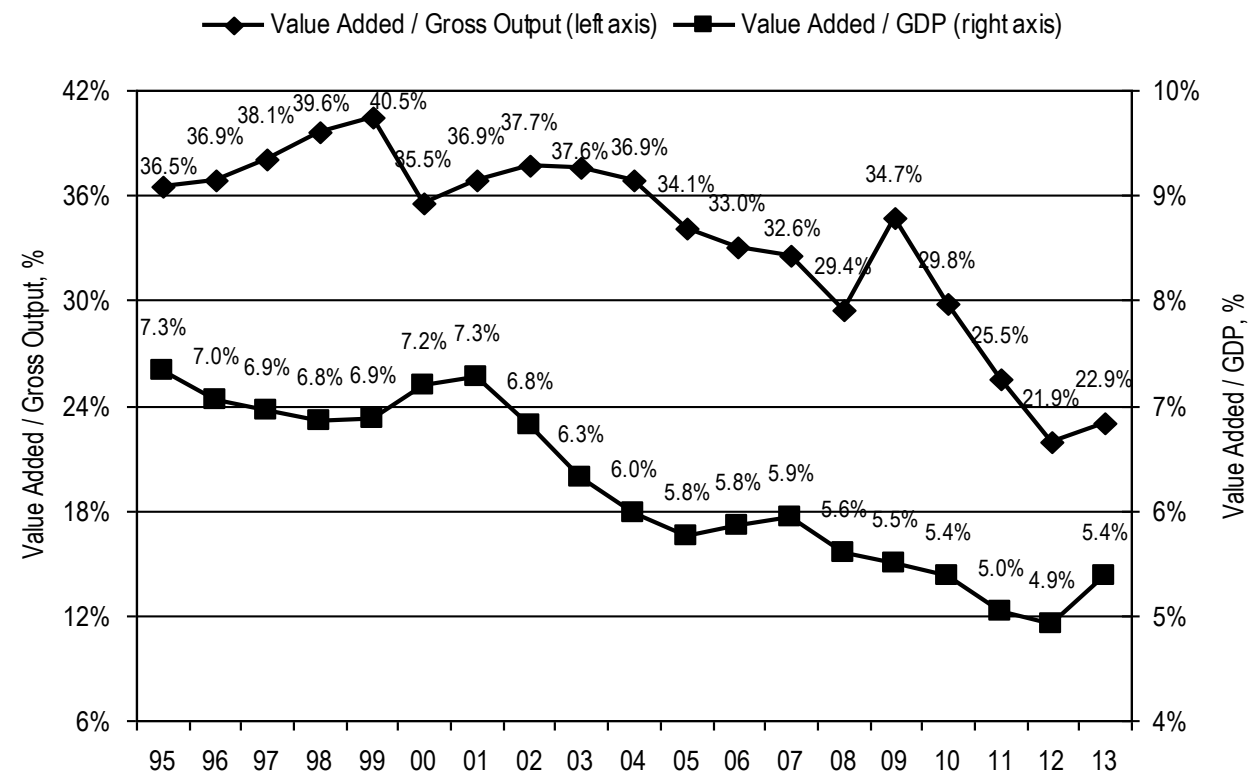

\section{Efficiency Indices of Manufacturing}

The key index for measuring the manufacturing sector efficiency is the industrial production index (Grima et al., 2015). Figure 5 illustrates the evolution of the industrial production index and the Gross Domestic Product (GDP - volume index) over the period 1995-2015 (provisional data). The shortfall of the industrial production growth rate compared to the growth rate of GDP is apparent.

During the pre-economic crisis period, 1995-2007, the average annual growth rate of GDP was $+4.0 \%$ and of the industrial production index just $+0.6 \%$. Since 2008 , the year that the first recession by $-0.4 \%$ occurred, up to 2013 , the average annual growth rate of GDP was $-5.5 \%$ and of the industrial production $-6.3 \%$. Thus, cumulatively over the period 2008 - 2013, GDP shrank by $-26.4 \%$ and industrial production by $-30.3 \%$. Finally, in the years 2014 and 2015, GDP changed by $+0.8 \%$ and $-0.2 \%$ and industrial production index by $+1.8 \%$ and $+1.9 \%$, respectively. It 
follows from the above that, unlike GDP which over the period considered 1995 2015 increased by $+17.6 \%$, industrial production declined by $-19.5 \%$.

What are the causes of the decline in industrial production? What had such a negative impact on manufacturing which for years is characterized by lack of investments, decrease in the number of manufacturing units, production shrinkage, leading to deindustrialization of the country? The answer is simple: The loss of competitiveness of the manufacturing sector.

The term "competitiveness" includes qualitative and quantitative characteristics. Qualitative characteristics are, for example, product quality, timely delivery, constant presence in the international market, etc. The quantitative aspect of competitiveness, which is examined in this study, pertains to two measurable factors that, according to international practice, are the most important ones, i.e. labor cost per product unit and labor productivity in manufacturing. These two indices measure the enterprise's competitiveness both in absolute terms, i.e. whether the enterprise improves, and in relative terms, i.e. whether the enterprise improves its competitiveness faster than its competitors.

Figure 5: Gross Domestic Product (Volume Index) and Industrial Production Index $(1995=100)$

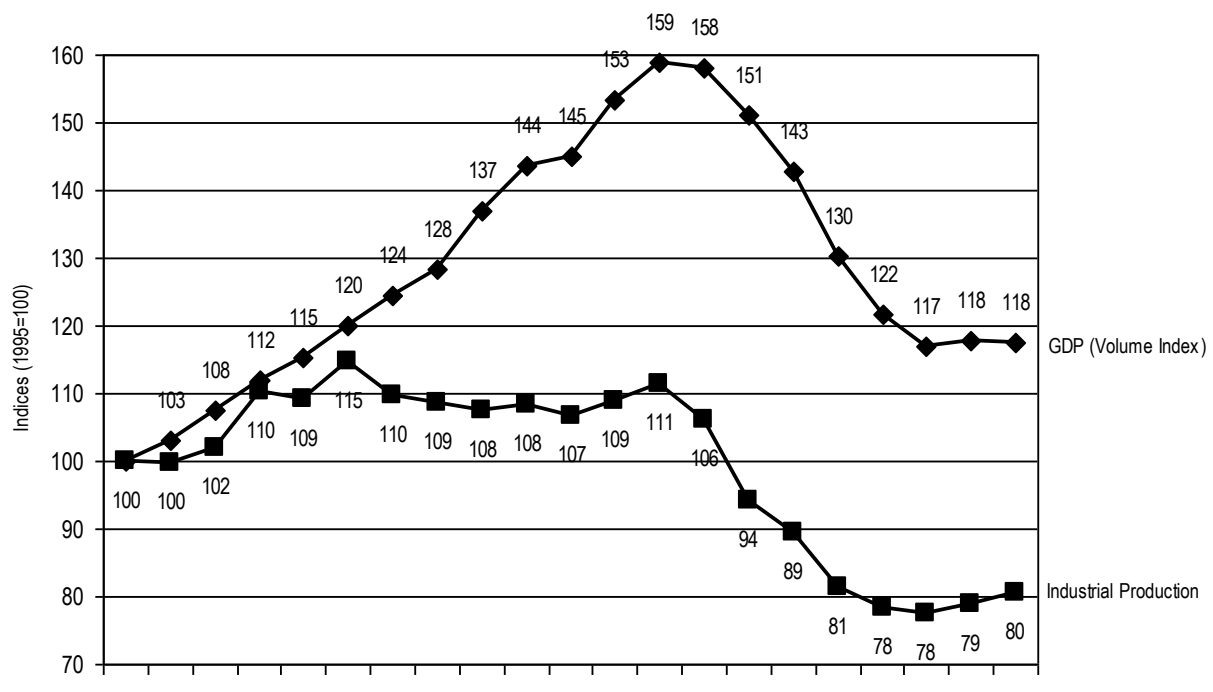

$\begin{array}{lllllllllllllllllllll}95 & 96 & 97 & 98 & 99 & 00 & 01 & 02 & 03 & 04 & 05 & 06 & 07 & 08 & 09 & 10 & 11 & 12 & 13 & 14 & 15\end{array}$

In the case of manufacturing that, in addition to the interior of the country, enterprises promote their products abroad, another measurable factor is the price of exported products. However, the export price index (either as an absolute or relative index, i.e. export prices compared to competitors' prices) has decreased reliability as a competitiveness measure for the following reason. Producers, in their effort to sell their products, raise prices less than the rate of increase in production costs (and 
therefore less than the decrease in competitiveness) thus squeezing their profits. Also, if the internal costs increase disproportionately, then it is possible the Greek exporters no to be able to sell at the price level shaped by international competition, since these prices cannot cover the production costs, resulting not only not to be competitive, but literally excluded from the international and sometimes the internal market. Thus, the level at which export prices are formed following a change in the internal costs of the enterprise is only of complementary character in the way of measuring competitiveness. The main factors of competitiveness must be sought in the internal costs of enterprises and this is measured, to a satisfactory extent, by labor costs per unit of output. Besides, in modern industry the main cost factors are approximately the same worldwide (oil, raw materials, production methods, machinery, etc.), resulting in the labor costs being the main differentiation factor of production costs and has prevailed as the main measurement index of manufacturing competitiveness.

The labor cost index per unit of output (or unit labor cost index - ULCI) arises from the relationship (total labor costs) / (production volume). Regarding competitor countries, the comparison of labor costs was limited to the European Union (EU). To facilitate comparison between the change in unit labor costs of Greek manufacturing and the change in unit labor costs in the EU countries, a relative index has been constructed, which represents the quotient obtained by dividing the unit labor cost index of Greek manufacturing by the respective index of competitor countries. Thus, increase in the relative index means that unit labor cost in the Greek manufacturing increases more than the unit cost in the manufacturing of our competitors and therefore the competitiveness of Greek manufacturing products decreases and vice versa. This relative index of unit labor costs has been calculated in a common currency (ECU) for the period before euro.

Figure 6: Unit Labour Costs Indices in Manufacturing (1995 = 100)

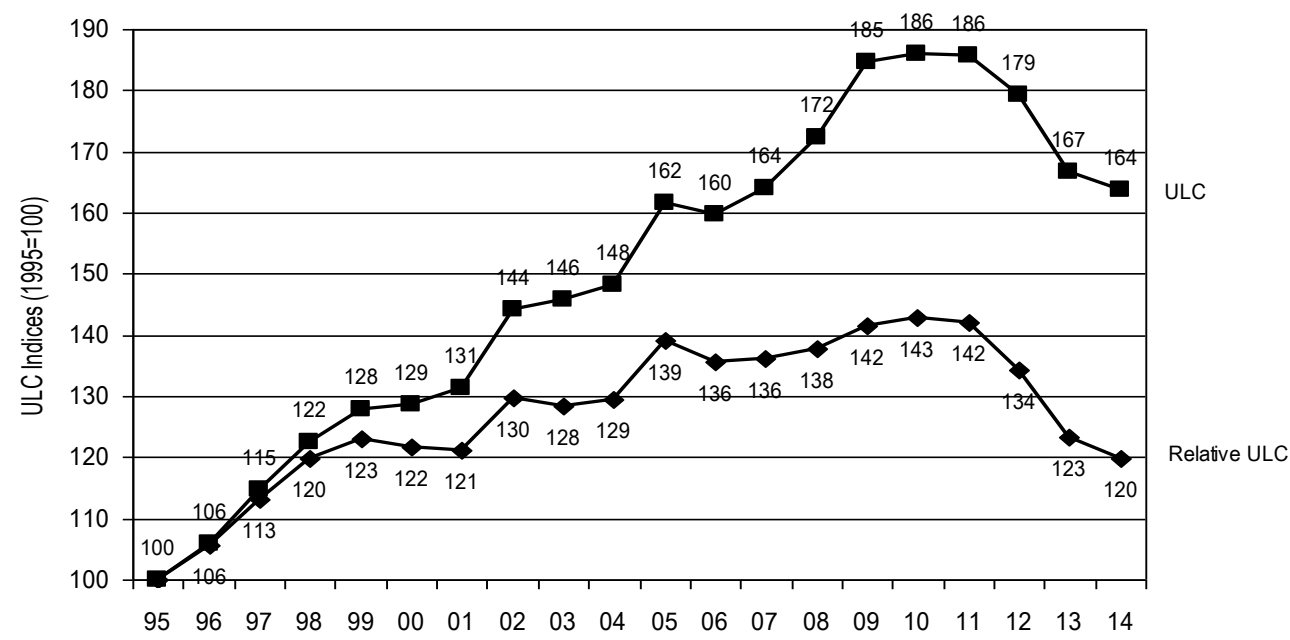


Figure 6 is revealing about the erosion suffered by the competitiveness of the Greek manufacturing sector during the period 1995-2011. The Unit Labor Cost Index (ULCI) increased cumulatively by $86 \%$ with an average annual growth rate of $+3.9 \%$, when the respective ULC index in the EU countries increased at an average annual rate of $1.9 \%$. The result was the Greek products to become cumulatively, in relative terms, by $43 \%$ more expensive than the products of our competitors. It is worth noting that, based on a previous study of the Exports Research Centre, the EU countries represent about two-thirds of the total competition faced by Greek products in international markets (Export Research Center, 2000; 2013).

The decrease in wages and salaries imposed by the creditors with the adjustment programmes led to decrease of ULC and improvement of the Relative ULCI in the years 2011-2013, resulting in offsetting about 50\% of the loss of competitiveness of Greek products. Main reasons for the increase in unit labor costs, and therefore the erosion of competitiveness, are the significant increase of wages and salaries and the disproportionately small, in relation to the first, increase in production volume in manufacturing. In other words, the increase in unit labor costs is the result of two opposing varying sizes: the labor compensation and its productivity. For example, on the hard Euro era and before crisis, 2000-2009, the basic labor cost in manufacturing almost doubled (average annual increase of National Collective Contracts $+5.5 \%$, maturity allowance $15 \%$ in the first 3 -year period, $13 \%$ in the second 3 -year period, $10 \%$ in the following four 3-year periods, $10 \%$ marriage allowance, $5 \%$ child allowance, etc.) leading to the collapse of manufacturing because the increase of productivity was clearly smaller than the increase of labor costs as detailed below.

Figure 7 shows the evolution of annual wage cost of an unskilled worker in the period 2002-2009 (7 years) which, for comparison purposes, was normalized so that the annual labor cost in 2002 to be equal to $€ 10,000.00$. Based on the above assumptions, the basic annual wage costs in the period 2002 - 2009 increased by $+89 \%$ for unmarried persons and by $+126.8 \%$ for married persons with two children.

The labor cost index per unit of output (or unit labor cost index - ULCI) is estimated according to the following formula:

$\mathrm{ULCI}=$

(Number of employees' index) $\mathrm{x}$ (Compensation index)

\section{Production volume index}

The numerator expresses the total wage costs and the denominator the production volume. This results in an index that measures labor costs per one unit of output over time. Also, the index of labor productivity equals:

Production volume index

Productivity Index = $\quad$ Number of employees' index 
It follows from the above that, the more the labor costs per unit of output decrease, the more the enterprise's competitiveness increases and vice versa. Also, the more the production volume per employee increases, the more productivity increases and vice versa.

Figure 7: Evolution of labour Cost in the period 2002 - 2009

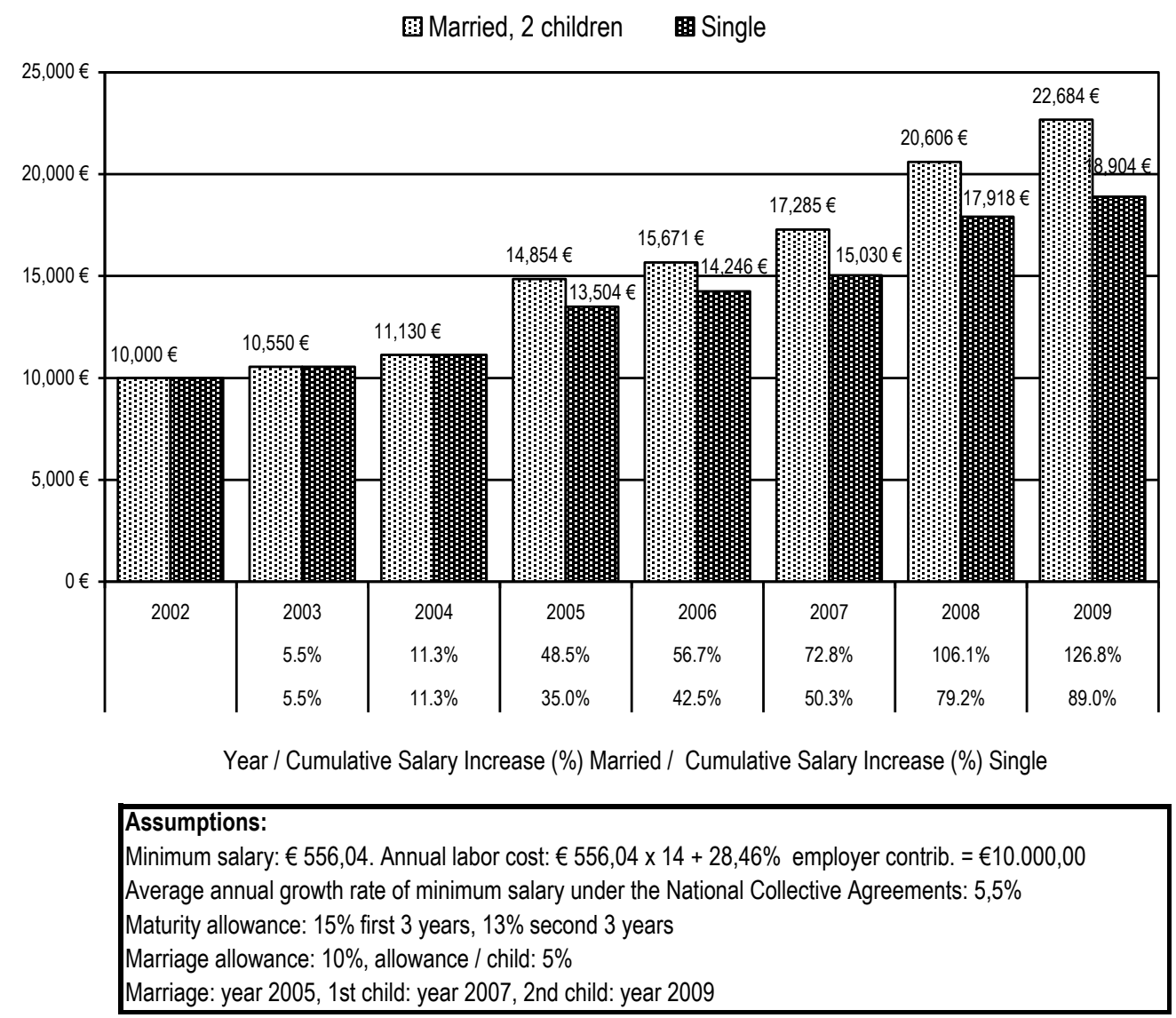

An alternative way of measuring the Unit Labor Costs arises from the above relationships:

\section{Compensation index}

ULCI =

(Production volume index) / (Number of employees index)

In other words, the Unit Labor Costs Index equals the Labor Compensation index divided by the Labor Productivity Index. This means that if productivity increases more than labor costs, then ULCI decreases and hence competitiveness improves and vice versa. 
Figure 8: Average Annual Costs and Labour Productivity Indices in Manufacturing $(1995=100)$

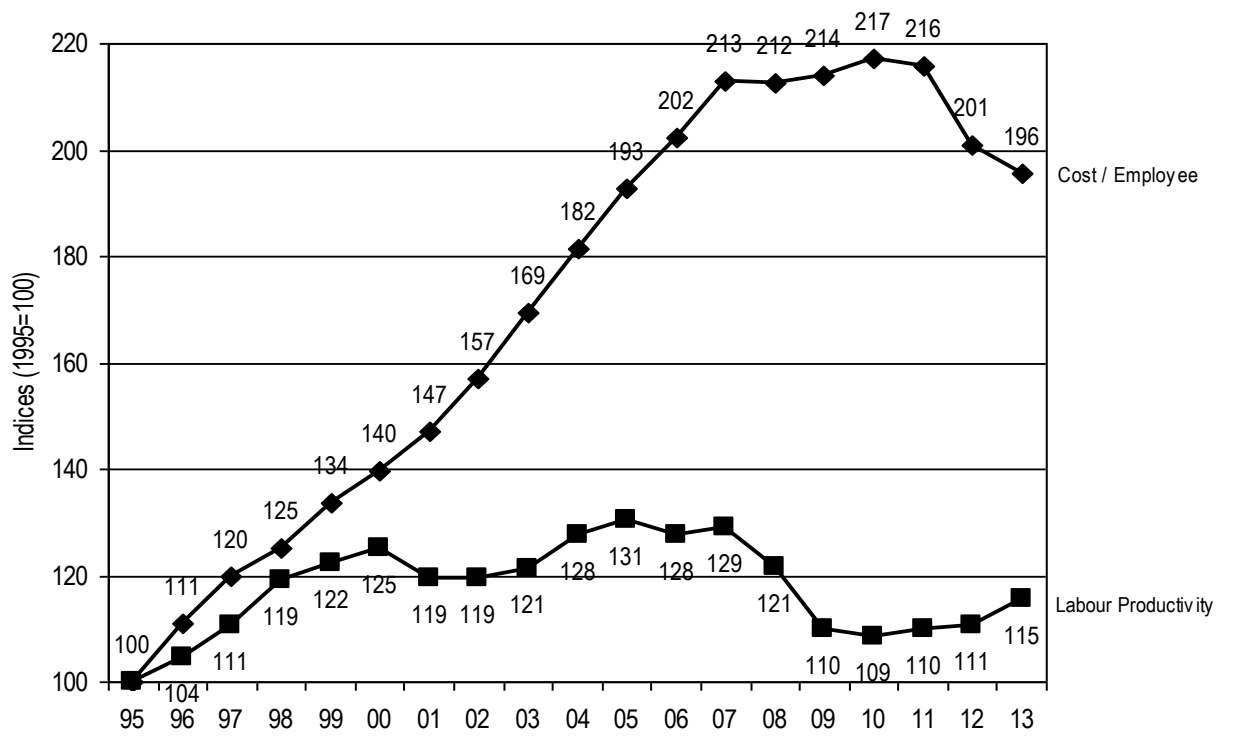

Figure 8 illustrates the evolution of the average annual costs per employee as well as the productivity index of Greek manufacturing. Now it becomes clear why the unit labor costs increased excessively. The average annual costs per employee in the period 1995 - 2010 increased by $117 \%$ while productivity improved only by $9 \%$. All scientific institutions of the country (KEPE, BoG, IOBE, PSE, etc.) already since 2000, when our country's entry in the Euro zone was routed, warned the social partners (SEB, GSEE, etc.) that joining the single currency deprived our country of the possibilities of national monetary policy by which, through the devaluations of the national currency, could, as in the past, offset the loss of competitiveness caused by the increase of wages and salaries. The constant erosion of competitiveness resulted in the shrinkage of several manufacturing sectors, especially those characterized as labor-intensive sectors (textiles, furniture and other manufacturing activities, clothing, footwear and travel goods).

\section{The Export Performance of Manufacturing}

In developing economies, exports are the main driver of industry growth, since through the applied economies of scale they improve their competitiveness leading to further increase of production and expansion of exports. The Greek manufacturing followed this rule and the openness of industry began from the early years of the country's industrialization. In recent years that our country is plagued by the economic crisis and domestic consumption continuously shrinks, exports became the only solution for the survival of manufacturing enterprises. Figure 9 is revealing 
about how much the openness of Greek manufacturing has increased during the years of crisis.

Extroversion is expressed by the ratio (exports) / (gross output). During the pre-crisis period, exports represented about $40 \%-43 \%$ of the gross output with a simultaneous increase or stability of industrial production (Figure 5). However, during the years of crisis, when the industrial production index continuously decreases with an average annual rate of $-6.3 \%$, exports increase and the extroversion index (exports/production) increased from $43.6 \%$ in 2007 to $62.6 \%$ in 2013.

At the same time, the Greek manufacturing to increase its export performance reduced its presence in the domestic market. The main reason was the low prices that prevailed in the Greek market due to crisis and reduced demand. In other words, manufacturing enterprises turned to foreign markets in which they offered their products at better prices and with better payment terms. This arises from the data of Figure 10 which shows the composition of domestic apparent consumption (production + imports - exports). If we subtract exports from the production, domestic production covers only $26 \%$ of domestic consumption, while the remaining $74 \%$ is satisfied by imports. It is worth noting that up to 2008 imports represented $70 \%$ or less of domestic consumption and consecutively increased to $74 \%$ in 2013 .

Figure 9: Extroversion of Greek Manufacturing (1995 - 2013)

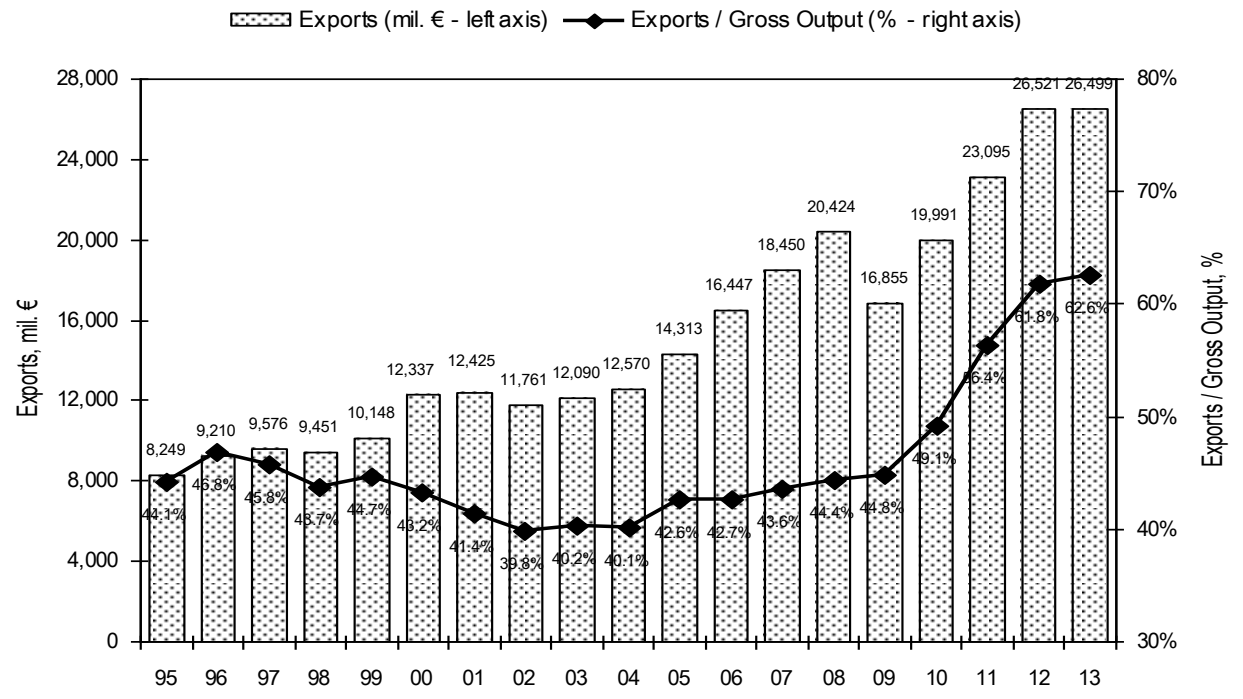

In other words, the domestically produced goods were replaced by cheaper imported products and this is apparent from the terms of trade (exports price index / imports price index). The terms of trade improved in the period $2009-2015$ by $+28.2 \%$, which means that during this period the export enterprises achieved abroad higher 
prices by $28.2 \%$ compared to the prices they would achieve in Greece (this happened to a large extent in the food \& beverage sector (Export Research Center, 2013).

Figure 10: Apparent Domestic Consumption (1995 - 2013)

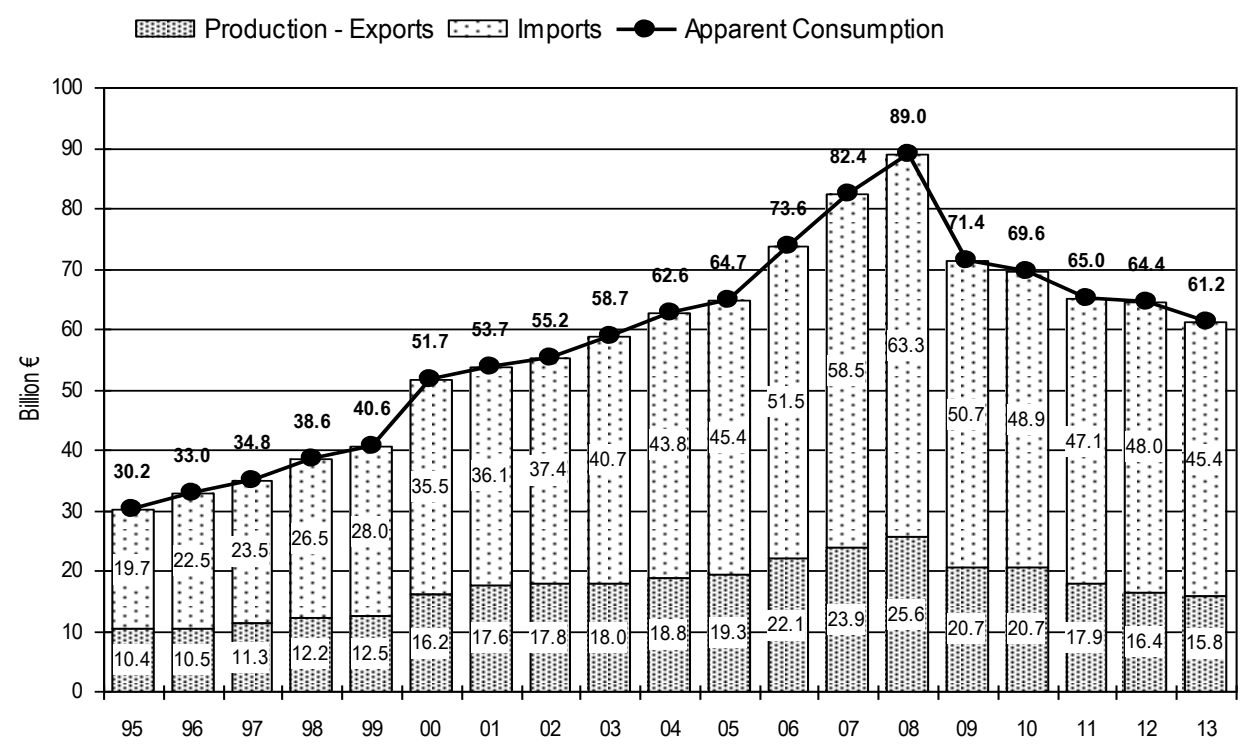

\section{Conclusions}

Over the last 20 years the Greek manufacturing is characterized by stagnation and subsequently a drastic decrease. During the pre-economic crisis period, 1995-2007, the average annual growth rate of the industrial production index was only $+0.6 \%$, and from 2008, the year that the first recession occurred, up to 2013, the average annual growth rate of the industrial production index was $-6.3 \%$. Thus, cumulatively over the period 2008-2013, industrial production shrank by $-30.3 \%$, and only in the years 2014 and 2015 increased by $+1.8 \%$ and $+1.9 \%$, respectively. It follows from the above that in the period 1995-2015, industrial production fell by $-19.5 \%$. The result of the manufacturing sector's shrinkage is a drastic decrease in investments, the number of manufacturing enterprises and the number of employees. Investments, after a dramatic increase in the period 1995-2000, follow a downtrend until 2005 and, after a recovery in 2006, 2007 and 2008 (due to investments in the sectors of Oil \& Coal and Chemical \& Pharmaceutical Products), continue their downtrend leading investments in 2013 to stand at 1995 levels. At the same time, manufacturing enterprises, from 5,814 in 1995, fell to 2,845 in 2013 and 82,090 jobs were lost (1995: 250,437 employees, 2013: 168,347 employees).

The gross output of manufacturing also shows a downtrend. After a continuous increase over the period 1995-2008 with an average annual growth rate of $+6,9 \%$ and the output amounting to $€ 46$ billion in 2008 , it fell to $€ 42.3$ billion in 2013, i.e. 
a cumulative decrease of $-8.1 \%$. The value added of manufacturing output was also significantly decreased. During the period 1995 - 2004, the value added was about $36 \%-40 \%$ of the gross output. After 2005, this percentage constantly decreases and fell to $22 \%$ and $23 \%$ in the years 2012 and 2013, respectively, resulting in the decrease of manufacturing participation in GDP. During the period 1995-2001, the percentage of GDP coming from the manufacturing sector was above 7\%. Since 2002, the participation percentage constantly decreases and reached $4.9 \%$ and $5.4 \%$ in the years 2012 and 2013, respectively.

The main cause of the manufacturing sector shrinkage is the erosion of competitiveness based on the unit labor cost index. The Unit Labor Cost Index (ULCI) increased cumulatively in the period 1995 - 2011 by $86 \%$, with an average annual growth rate of $+3.9 \%$, when the respective ULC index in the EU countries increased at an average annual rate of $1.9 \%$. The result was the Greek products to become cumulatively, in relative terms, by $43 \%$ more expensive than the products of our competitors.

The decrease in wages and salaries imposed by the creditors with the adjustment programmes led to decrease of ULC and improvement of the Relative ULCI in the years 2011 - 2013, resulting in offsetting about $50 \%$ of the loss of competitiveness of Greek products. Main reasons for the increase in unit labor costs are the significant increase of wages and salaries and the disproportionately small, in relation to the first, increase in production volume in manufacturing. In other words, the increase in unit labor cost is the result of two opposing varying sizes: the labor compensation and its productivity. Suffice it to say that in the period 1995-2010 the average annual labor costs increased by $+117 \%$ and productivity only by $+9 \%$. A convergence between the two indices is observed in the period 2010-2013, when the average annual labor costs decreased by $-10 \%$ and productivity increased by $+6 \%$.

Exports are the only solution for the survival of manufacturing enterprises and for the time when our country is plagued by the economic crisis and the internal consumption is constantly shrinking. After continuous growth in exports during the period 1995 - 2008 with an average annual growth rate of $+6.4 \%$, a decrease by $17.5 \%$ follows in 2009 due to the international crisis. Since then, exports are changing in a positive rate, recording a cumulative increase of $+57.2 \%$ in the period 2009-2013.

The significant improvement in the manufacturing sector extroversion is revealed by the increase of the exports / gross output index. During the pre-crisis period, exports represented about $40 \%$ - $43 \%$ of the gross output (with industrial production approximately unchanged). However, during the years of crisis, when the industrial production index continuously decreases, exports increase and the extroversion index (exports / production) increased from $43.6 \%$ in 2007 to $62.6 \%$ in 2013. In other words, the survival of manufacturing sector depends almost exclusively on exports. 


\section{References:}

Grima, S., Romānova, I., Bezzina, F. and Dimech, C.F. 2016. Alternative Investment Fund Managers Directive and its Impact on Malta's Financial Service Industry. International Journal of Economics and Business Administration, 4(1), 70-85.

Keisidou, E., Sarigiannidis, L., Maditinos, D. and Thalassinos, I.E. 2013. Customer satisfaction, loyalty and financial performance: A holistic approach of the Greek banking sector in Marketing Intelligence and Planning, 31(4), 259-288, Emerald Group Publishing Ltd., DOI: 10.1108/IJBM-11-2012-0114.

Liapis, K., Rovolis, A., Galanos, C. and Thalassinos, I.E. 2013. The Clusters of Economic Similarities between EU Countries: A View Under Recent Financial and Debt Crisis. European Research Studies Journal, 16(1), 41-66.

Thalassinos, I.E. and Stamatopoulos, V.T. 2015. The Trilemma and the Eurozone: A PreAnnounced Tragedy of the Hellenic Debt Crisis. Journal of Economics and Business Administration, 3(3), 27-40.

Thalassinos, I.E. and Dafnos, G. 2015. EMU and the process of European integration: Southern Europe's economic challenges and the need for revisiting EMU's institutional framework. Chapter book in Societies in Transition: Economic, Political and Security Transformations in Contemporary Europe, 15-37, Springer International Publishing, DOI: 10.1007/978-3-319-13814-5_2.

Thalassinos, I.E., Stamatopoulos, D.T. and Thalassinos, E.P. 2015. The European Sovereign Debt Crisis and the Role of Credit Swaps. Chapter book in The WSPC Handbook of Futures Markets (eds) W. T. Ziemba and A.G. Malliaris, in memory of Late Milton Miller (Nobel 1990) World Scientific Handbook in Financial Economic Series Vol. 5, Chapter 20, pp. 605-639, ISBN: 978-981-4566-91-9, (doi: 10.1142/9789814566926_0020).

The Competitiveness of Greek Exported Commodities during the Period 1961 - 1983: A Quantitative Analysis, Export Research Center, Athens, June 1985

The Competitiveness of Greek Exported Commodities During the Period 1980 - 1985: A Quantitative Analysis, Export Research Center, Athens, May 1987

The Export Performance of Greek Manufacturing: A Sectoral Analysis, Export Research Center, Athens, October 1995

The Main Competitors of Greece in Exports to European Union, Export Research Center, Athens, October 2000

The Evolution of Exports of Agricultural Products during the Period 1988 - 2011; Trends, International Competition, Shares in the Foreign Markets, Export Research Center, Athens, January 2013. 